\title{
OPEN Histological changes in human skin 32 days after death and the potential forensic significance
}

\author{
Wang Wei ${ }^{1,6}$, Qi Michu ${ }^{1,6}$, Dong Wenjuan ${ }^{1,2}$, Wen Jianrong ${ }^{1}$, Han Zhibing ${ }^{3}$, Yang Ming ${ }^{1,3}$, \\ Jin $\mathrm{Bo}^{1 \bowtie}$ \& Lin $\mathrm{Xia}^{4,5}$
}

To observe the histological changes in human skin within 32 days after death to explore its potential significance in forensic practice. The intact full-thickness skin and subcutaneous tissue from the sternum of eight corpses were placed in an environment of $4-6^{\circ} \mathrm{C}$ for $4 \mathrm{~h}, 6 \mathrm{~h}, 12 \mathrm{~h}, 18 \mathrm{~h}, 24 \mathrm{~h}, 36 \mathrm{~h}$, $48 \mathrm{~h}, 60 \mathrm{~h}, 72 \mathrm{~h}, 84 \mathrm{~h}, 96 \mathrm{~h}, 6 \mathrm{~d}, 8 \mathrm{~d}, 10 \mathrm{~d}, 12 \mathrm{~d}, 16 \mathrm{~d}, 20 \mathrm{~d}, 24 \mathrm{~d}, 28 \mathrm{~d}$, and $32 \mathrm{~d}$. Then, the whole layer of the skin was stained with haematoxylin \& eosin. The histological morphology of the epidermis, dermis and appendages (sweat glands, hair follicles, and sebaceous glands) was observed under an light microscope. The epithelial nucleus condensed at $24 \mathrm{~h}$ after death, and cell lysis was exhausted after 20 days. The post-mortem changes in the dermis occurred later than that of the epidermis (72 h), but after epidermal changes started, the change was more rapid. At $16 \mathrm{~d}$, the layers had become homogenized. The epidermis and dermis had completely separated $24 \mathrm{~d}$ after death. The changes in the sweat glands appeared earlier ( $24 \mathrm{~h}$ ) and disappeared later (32 days); the sebaceous glands and hair follicles began to undergo degenerative changes at $96 \mathrm{~h}$ after death, and at approximately 20 $\mathrm{d}$, only their contour remained. There were individual and structural differences in the post-mortem histological changes in the skin. At $4-6^{\circ} \mathrm{C}$ ambient temperature, some structures of the human skin still exist for a long time after death, and these structures can be used to identify the source of the tissue; post-mortem histological changes in the skin occur at specific times, which can be used to help infer the time of death. A comprehensive observation of changes in the skin composition/structure is required to comprehensively analyse possible death times.

Accurate estimation of time of death or post-mortem interval (PMI) has always been the focus and a primary difficulty of forensic pathology. People have tried to use many ways to infer the time of death. Changes to the skin occur at different times after the death of the body. The general morphology of the skin after death and the changes in histology, biomechanics ${ }^{1}$, temperature, spectral characteristics ${ }^{2-4}$, microbes ${ }^{5-9}$, skin resistivity ${ }^{10,11}$ and other factors ${ }^{12,13}$ have been studied, and some progress has been made, but it has not been enough to be applied to actual situations and to be used to infer the time of death accurately.

The skin is a relatively long-lived body tissue after death. Previous studies ${ }^{14,15}$ have shown that morphological changes in experimental animals and human skin after death correlate with time. However, until now, there have been few studies ${ }^{14}$ on histological changes in human skin after death, and the time after death involved in most prior studies has been relatively short. This study looked at the histological changes in isolated human skin for a longer time after death to explore their potential significance in forensic practice, such as time of death inference.

\footnotetext{
${ }^{1}$ Department of Forensic Medicine, North Sichuan Medical College, Nanchong 637000, People's Republic of China. ${ }^{2}$ School of Forensic Medicine, Kunming Medical University, Kunming 650500, People's Republic of China. ${ }^{3}$ Nanchong Public Security Bureau, Nanchong 637000, People's Republic of China. ${ }^{4}$ Department of Clinical Medicine, North Sichuan Medicine College, Nanchong 637000, People's Republic of China. ${ }^{5}$ Department of Rehabilitation Medicine, Affiliated Hospital of North Sichuan Medicine College, Nanchong 637000, People's Republic of China. ${ }^{6}$ These authors contributed equally: Wang Wei and Qi Michu. ${ }^{\square}$ email: jinbo@nsmc.edu.cn; linxia@nsmc.edu.cn
} 


\section{Methods}

Study design and participants. In this study, eight cadavers were randomly obtained, aged between 22 and 33 years old, including two women and six men, BMI 21.2-23.3. One donor died from mechanical asphyxia, and the other seven died from a mechanical injury. The eight donors were healthy before their death, with no skin diseases and no skin damage or scars.

Materials. Bouin's solution, ethanol, xylene, paraffin (Chengdu Kelong Chemical Reagent Factory, China) and haematoxylin and eosin (Shanghai Fusheng Industrial Co., Ltd., China) were obtained. The slices were viewed using an Olympus BX-43 microscope (Japan). We used cellSens Standard software (Version 1.2.1) to collect the pictures.

Haematoxylin eosin staining. All cadavers were dissected within four hours of death. The skin in the chest area of the human body was selected in this study as it is a non-articular surface, and the subcutaneous tissue is thinner and less affected by obesity, Sun exposure, friction and damage. The whole layer of the skin and subcutaneous tissue from the sternum angle to the xiphoid process was removed by a surgical blade. The piece was trimmed to $10 \mathrm{~cm} \times 2 \mathrm{~cm}$ (length $\times$ width), and then, the sample was placed flat in a refrigerator at $4-6{ }^{\circ} \mathrm{C}$. At different PMIs $(4 \mathrm{~h}, 6 \mathrm{~h}, 12$ h, 18 h, 24 h, 36 h, 48 h, 60 h, 72 h, 84 h, 96 h, 6 d, 8 d, 10 d, 12 d, 16 d, 20 d, 24 d, $28 \mathrm{~d}$, and $32 \mathrm{~d}$ ) a piece measuring $0.3 \mathrm{~cm} \times 1.0 \mathrm{~cm}$ was extracted from each sample.

The samples were immersed in Bouin's solution for four days, transferred to $70 \%$ ethanol, dehydrated through a serial alcohol gradient, and embedded in paraffin wax blocks. The sample sections were dewaxed in xylene and rehydrated through decreasing concentrations of ethanol. Then, they were subjected to H\&E staining. We observed the slices and recorded the results. The changes in the epidermis, dermis, sweat glands, hair follicles and sebaceous glands were observed.

Ethics. The experiments were carried out in accordance with the Declaration of Helsinki (1983) of the World Medical Association, and the protocols were approved by the Institutional Research Review Board at North Sichuan Medical College (201810634009) with informed consent for study participation from next of kin/ legal representative(LAR).

\section{Results}

The skin samples from the different bodies changed almost uniformly after death. The time and rate of change of the individual samples after death for certain structures were different. The following description is based on the observational results of the eight cadavers.

Epidermis and dermis (Table 1). The epidermis is composed of layers of squamous epithelial cells, including the stratum corneum, the transparent layer, the granular layer, the spinous layer, and the basal layer. Because the chest epidermis is thin, the layers are difficult to distinguish completely, and the changes are basically synchronized, so their descriptions are combined. The epidermal layer shows no obvious change at the time of death(Fig. 1A). No obvious changes were observed in the early post-mortem $(<24 \mathrm{~h})$, but nuclear pyknosis began to appear in the cells after $24 \mathrm{~h}$. With the prolongation of PMI, the cell degeneration and gradual changes such as nuclear fragmentation and lysis gradually increased (Fig. 1B). The dermis was focally isolated (Fig. 1C), and on the 20th day, the epidermal cells were all dissolved (Fig. 1D). On the $24^{\text {th }}$ day, the dermis was completely separated (Fig. 1E), and the epidermis disappeared at $32 \mathrm{~d}$.

The dermis is mainly composed of connective tissue, which is divided into a papillary layer and a reticular layer that are roughly demarcated by shallow blood vessels. The papillary layer is thin, and it has papillary protrusions (dermal nipples) on the epidermis side, which are intertwined with the epidermis to form a corrugated and firm link. The collagen fibres of the papillary layer are slender and disorderly, and they are only stained lightly with H\&E. The dermal mesh is thicker, and the collagen fibre bundles are thick, mostly parallel to the epidermis, and they are intertwined with each other. The H\&E staining shows red-dyed corrugations in the longitudinal and transverse directions, which are indistinguishable from the elastic fibres. The early dermal fibre changes were not obvious shortly after death (Fig. 2A). At $72 \mathrm{~h}$, some fibre swelling was observed, and it gradually increased (Fig. 2B). Focal fibre dissolution was observed by the sixth day, and by the $16 \mathrm{~d}$, dermal fibres were observed, and extensive homogenization had occurred (Fig. 2C).

Sebaceous glands, sweat glands and hair follicles (Table 2). The sebaceous glands are closely related to the hair follicles. Most of the sebaceous glands open in the funnel of the hair follicle. The peripheral part of the sebaceous gland is the basal cell, and the inside consists of sebocytes. The sebaceous glands show no obvious change at the time of death (Fig. 3A). Before $84 \mathrm{~h}$, no significant structural changes were seen in the sebaceous glands. From $96 \mathrm{~h}$, the nucleus of the sebocytes gradually dissolved and disappeared, and the cytoplasm changed and increased (Fig. 3B,C). At $24 \mathrm{~d}$, the sebocytes and basal cells were completely dissolved. At $28 \mathrm{~d}$, no sebaceous gland tissue was seen.

The sweat gland is divided into a secretory part and a duct. The secretory part is composed of a single layer of cubic epithelium. The single layer of cubic epithelium is composed of dark cells and clear cells, which are surrounded by myoepithelial cells. The ductal epithelium is composed of two layers of small, basophilic cuboidal cells, while the lumen is lined by a ring of uniform eosinophilic utricles. The sweat gland show no obvious change at the time of death (Fig. 3D). After $24 \mathrm{~h}$, vacuoles appeared in the cytoplasm of the sweat gland cells. After that, 


\begin{tabular}{|c|c|c|}
\hline PMI & Epidermal histology change & Dermis histology change \\
\hline $0-18 \mathrm{~h}$ & No obvious change & No obvious change \\
\hline $24 \mathrm{~h}$ & $\begin{array}{l}\text { The cell layer occasionally showed nuclear pyknosis; no obvious changes were } \\
\text { observed in the stratum corneum }\end{array}$ & No obvious change \\
\hline $36 \mathrm{~h}$ & $\begin{array}{l}\text { Scattered nuclear fragmentation is seen in the cell layer, showing nuclear pyknosis; } \\
\text { the stratum corneum changes as above }\end{array}$ & No obvious change \\
\hline $48 \mathrm{~h}$ & $\begin{array}{l}\text { The cell layer occasionally shows nuclear lysis, local visible nuclear pyknosis, rare } \\
\text { nuclear fragmentation; local swelling of the stratum corneum }\end{array}$ & No obvious change \\
\hline $60 \mathrm{~h}$ & $\begin{array}{l}\text { The cell layer occasionally shows nuclear lysis, local visible nuclear pyknosis, rare } \\
\text { nuclear fragmentation; local swelling of the stratum corneum }\end{array}$ & No obvious change \\
\hline $72 \mathrm{~h}$ & $\begin{array}{l}\text { The cell layer shows less nuclear pyknosis, visible nuclear fragmentation, rare } \\
\text { nuclear dissolution; stratum corneum swelling }\end{array}$ & $\begin{array}{l}\text { There is a small amount of fibre swelling, and there is no obvious change in the } \\
\text { whole }\end{array}$ \\
\hline $84 \mathrm{~h}$ & $\begin{array}{l}\text { The cell layer shows less nuclear pyknosis, visible nuclear fragmentation, rare } \\
\text { nuclear dissolution; stratum corneum swelling }\end{array}$ & Visible fibre swelling, no significant change in the overall \\
\hline $96 \mathrm{~h}$ & $\begin{array}{l}\text { Cell layer cell gap widened; more nuclear pyknosis, nuclear fragmentation, nuclear } \\
\text { dissolution; stratum corneum changes as above }\end{array}$ & Visible fibre swelling, no significant change overall \\
\hline $6 \mathrm{~d}$ & \begin{tabular}{|l|l} 
Cell layer changes as above; the stratum corneum is swollen \\
\end{tabular} & Significant swelling of the fibres, visible focal fibre dissolution \\
\hline $8 \mathrm{~d}$ & $\begin{array}{l}\text { The epidemal layer is thin; the cell layer is basically free of normal cells, with nucleus } \\
\text { pyknosis, nuclear fragmentation, and nuclear dissolution; the stratum corneum is } \\
\text { swollen, and a purple foam-like stain layer is visible on the surface }\end{array}$ & $\begin{array}{l}\text { The papillary layer fibres are dissolved, the reticulated fibres are arranged in order, } \\
\text { the swelling is obvious, and there is focal dissolution }\end{array}$ \\
\hline $10 \mathrm{~d}$ & $\begin{array}{l}\text { The local dermis began to separate; the cell layer and stratum corneum changed as } \\
\text { above }\end{array}$ & $\begin{array}{l}\text { The papillary layer fibres are dissolved, the reticulated fibres are arranged in order, } \\
\text { the swelling is obvious, and there is focal dissolution }\end{array}$ \\
\hline $12 \mathrm{~d}$ & $\begin{array}{l}\text { The cells in the cell layer are disorderly, their boundaries are unclear, the number of } \\
\text { cells is reduced, and the remaining changes are the same as above }\end{array}$ & $\begin{array}{l}\text { The papillary layer is homogeneous, the woven layer is partially dissolved, and the } \\
\text { remaining fibres are swollen }\end{array}$ \\
\hline $16 \mathrm{~d}$ & $\begin{array}{l}\text { The number of cells in the cell layer is further reduced, and the remaining changes } \\
\text { were the same; there was a contiguous purple-blue staining area at the junction of } \\
\text { the epidermis and the dermis; the stratum corneum was severely swollen }\end{array}$ & Both the papillary layer and the woven layer are homogenized \\
\hline $20 \mathrm{~d}$ & $\begin{array}{l}\text { The cells in the cell layer are all dissolved, the epidemal is a purple-blue stained area, } \\
\text { the stratum corneum changes are the same as above, and the epidemal is mostly } \\
\text { separated from the dermis }\end{array}$ & Both the papillary layer and the woven layer are homogenized \\
\hline $24 \mathrm{~d}$ & Completely separated from the dermis, the remaining changes are the same as above & $\begin{array}{l}\text { The fibre dissolves into a homogeneous shape, and the papillary layer and the woven } \\
\text { layer cannot be distinguished }\end{array}$ \\
\hline $28 \mathrm{~d}$ & Completely separated from the dermis, the remaining changes are the same as above & $\begin{array}{l}\text { The fibre dissolves into a homogeneous shape, and the papillary layer and the woven } \\
\text { layer cannot be distinguished }\end{array}$ \\
\hline $32 \mathrm{~d}$ & The epidemal disappears, and the purple-blue stained area disappears & Fragmented, flaky \\
\hline
\end{tabular}

Table 1. Histological changes in the human epidermis and dermis 32 days after death.

the degeneration of the cells increased, and it was most obvious at 10-12 days (Fig. 3E). On the 16th day, only the residual sweat gland structure was observed (Fig. 3F), and no sweat gland structure was observed on the 32nd day.

The hair follicle is divided into three parts: the opening of the sebaceous gland duct and the attachment of the pilose muscle: the funnel, the isthmus and the lower part of the hair follicle. The epithelium of the funnel of the hair follicle is connected with the epidermis, and the morphology is exactly the same. The lower part of the hair follicle is swollen into a ball, and the centre has an inward depression, that is, a dermal papilla. The hair follicle show no obvious change at the time of death (Fig. 3G). No significant change was observed before $72 \mathrm{~h}$. At $16 \mathrm{~d}$, most of the hair follicle cells had dissolved and disappeared. No hair follicle structure was seen from 24 d (Fig. 3H,I).

\section{Discussion}

The theory and technique of histology and pathology is the basis of classical forensic science. H\&E staining is a simple, reliable and economical technical means to observe histomorphology ${ }^{15}$. Kovarik ${ }^{16}$, studied the appearance of three corpses in the outdoors, dark, at $3-25^{\circ} \mathrm{C}$ in the early post-mortem (one week) period by skin microscopy and found that epidermis and dermis separation occurred four to six days after death. The degeneration of the sweat glands was obvious at five days after death, and the dermis degeneration appeared two days after death. Bardale et al. ${ }^{14}$ studied the histological changes in post-mortem skin of 30 human cadavers at $23-37^{\circ} \mathrm{C}$. Their study showed that after nine to $12 \mathrm{~h}$ of death, the basal cells of the epidermis began to deform, and the surface and dermis were partially separated. After $12-18 \mathrm{~h}$ of death, the epidermis and dermis were separated, and the dermis began to separate $18 \mathrm{~h}$ after death. The sweat gland cells underwent vacuolar degeneration four hours after death, with an increase of PMI, and the amount of cell vacuolar degeneration increased. At approximately $15 \mathrm{~h}$, the cells ruptured; after $18 \mathrm{~h}$ of death, the sebaceous glands increased with PMI, the sebocytes lost their cell structure and the nuclei dissolved; the hair follicles died $18 \mathrm{~h}$ after death. There were degenerative changes, and the papilla was broken down.

The post-mortem changes in the skin in the chest area of our eight corpses were generally consistent with those observed by Kovarik and Bardale, but the time of appearance was relatively late, and the rate of change was slower. A long time after death, they were still observed. Some structures of the skin, hair follicles, sebaceous glands, and sweat glands still partially survived after 20-28 days of death, which could be related to the lower ambient temperature $\left(4-6{ }^{\circ} \mathrm{C}\right)$ of the skin samples in our study. Thus, at certain ambient temperatures, certain 


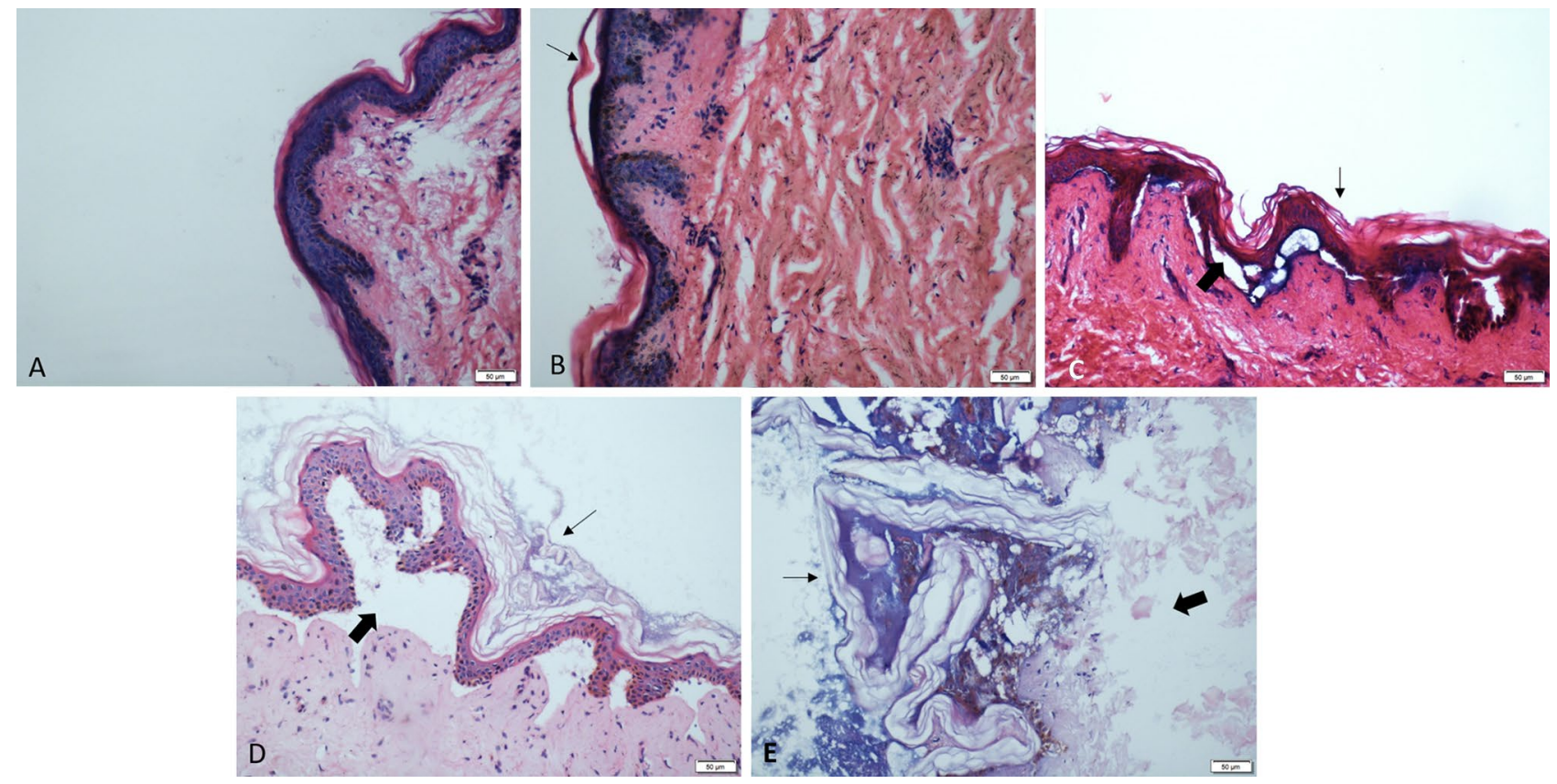

Figure 1. Microphotograph showing the epidermis. (A) The epidermal layer shows no obvious change at the time of death. (B) Focal nuclear retraction of the epidermis and local swelling of the stratum corneum (small black arrows) $48 \mathrm{~h}$ after death. (C) Focal surface dermal separation (bold black arrows) 10 days after death. (D) Complete dissolution of the epidermal cells, the stratum corneum is severely swollen, and the epidermis is mostly separated from the dermis twenty days after death. (E) Complete separation of the epidermis 24 days after death. ( $\mathrm{H}$ and $\mathrm{E}$, original magnification $\times 20$, small black arrows point to changes in the cuticle, the bold black arrows point to the separation of the dermis and epidermis). (All images are collected by cellSens Standard software whose URL is https://www.olympus-lifescience.com.cn/en/software/cellsens/).
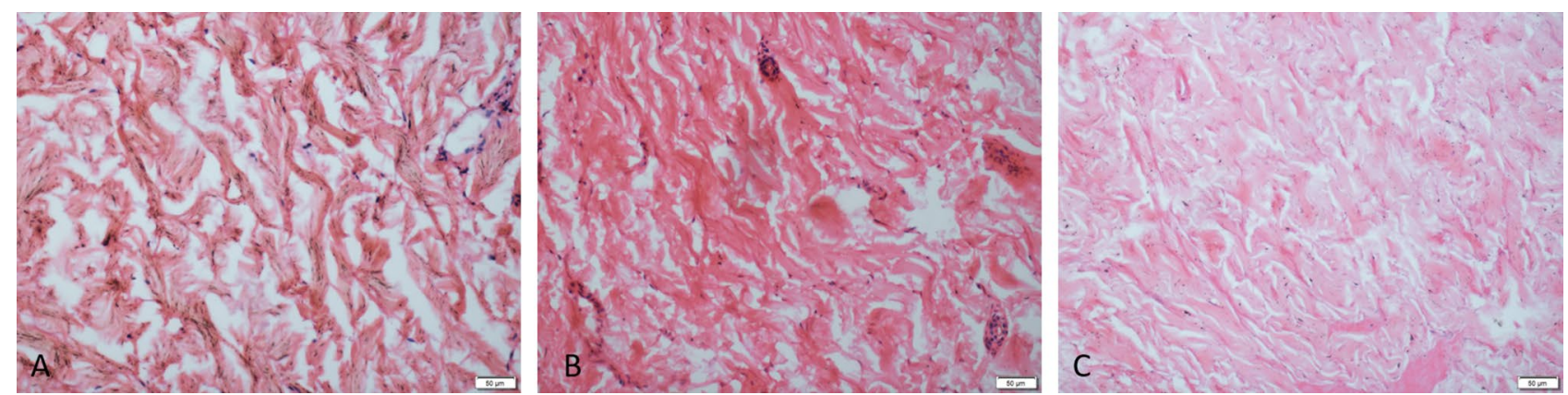

Figure 2. Microphotograph showing the dermis. (A) The dermis layer shows no obvious change at the time of death. (B) Fibre swelling $96 \mathrm{~h}$ after death. (C) Homogenization of dermal fibres twenty days after death ( $\mathrm{H}$ and E, original magnification $\times 20$ ). (All images are collected by cellSens Standard software whose URL is https:// www.olympus-lifescience.com.cn/en/software/cellsens/).

structures of human skin are still identifiable for a long time after death, which has potential applications in the identification of the sources of biological tissue fragments.

The observations in our study suggest that post-mortem changes in the epidermis, dermis, and skin appendages show a certain degree of time compliance, such as the changes in the epidermal cells and hair follicle cells. The changes in these two within $84 \mathrm{~h}$ after death were not obvious. Then, changes such as nuclear pyknosis karyorrhexis and karyolysis occurred as the PMI increased. On the 20th day after death, the cells of these two structures were almost completely dissolved. The hair follicles continue from the epidermis, especially the cell layer of the follicular infundibulum, which is the same as the epidermis, which explains the synchrony of the changes.

At some specific time points, the structure of the skin has prominent characteristics, such as at 16 days after death. At this time, the stratum corneum of the skin epidermis is obviously swollen, and the cells have obvious 


\begin{tabular}{|c|c|c|c|}
\hline PMI & Sweat glan & Sebaceous gland & Hair follicle \\
\hline $0-24 \mathrm{~h}$ & 24-h vacuoles began to appear in the cytoplasm & No obvious change & No obvious change \\
\hline $36 \mathrm{~h}$ & $\begin{array}{l}\text { Interstitial swelling occurs; the sweat gland epithelial } \\
\text { cells become smaller }\end{array}$ & No obvious change & No obvious change \\
\hline $48 \mathrm{~h}$ & $\begin{array}{l}\text { Interstitial swelling occurs; the sweat gland epithelial } \\
\text { cells become smaller }\end{array}$ & No obvious change & No obvious change \\
\hline $60 \mathrm{~h}$ & $\begin{array}{l}\text { The gland tube becomes smaller, the interstitial is swol- } \\
\text { len, and the focal cytoplasm has vacuoles }\end{array}$ & No obvious change & No obvious change \\
\hline $72 \mathrm{~h}$ & The nucleus is swollen and the cytoplasm has vacuoles & No obvious change & No obvious change \\
\hline $84 \mathrm{~h}$ & $\begin{array}{l}\text { The cavity in the centre of some sweat glands disap- } \\
\text { pears, the basement membrane of the sweat gland } \\
\text { is locally swollen, and the epithelial cells are focally } \\
\text { separated from the basement membrane }\end{array}$ & No obvious change & $\begin{array}{l}\text { Occasionally, under high magnification, the cells are } \\
\text { swollen, the hair follicles are dissolved at the roots, } \\
\text { and the inner and outer layers of the hair follicles are } \\
\text { separated (longitudinal section) }\end{array}$ \\
\hline $96 \mathrm{~h}$ & $\begin{array}{l}\text { Epithelial cell disorder, a small amount of nuclear } \\
\text { pyknosis, nuclear fragmentation, nuclear lysis; cell and } \\
\text { basement membrane detachment }\end{array}$ & $\begin{array}{l}\text { The sebaceous cell nucleus is irregular, and the cyto- } \\
\text { plasm begins to show flocculation changes }\end{array}$ & $\begin{array}{l}\text { Hair follicle cells visible, nuclear pyknosis, nuclear } \\
\text { fragmentation, nuclear dissolution }\end{array}$ \\
\hline $6 \mathrm{~d}$ & $\begin{array}{l}\text { Epithelial cells have more nuclear pyknosis, nuclear } \\
\text { fragmentation, nuclear lysis, and unclear cell bounda- } \\
\text { ries }\end{array}$ & $\begin{array}{l}\text { The sebaceous cell nucleus is dissolved, and the cyto- } \\
\text { plasm is flocculated }\end{array}$ & $\begin{array}{l}\text { The gap of the hair follicle cells is widened, and the } \\
\text { remaining changes are the same as above }\end{array}$ \\
\hline $8 \mathrm{~d}$ & $\begin{array}{l}\text { Epithelial cells have more nuclear pyknosis, nuclear } \\
\text { fragmentation, nuclear lysis, and unclear cell bounda- } \\
\text { ries }\end{array}$ & $\begin{array}{l}\text { The sebaceous cell nucleus is dissolved, and the cyto- } \\
\text { plasm is flocculated }\end{array}$ & $\begin{array}{l}\text { The gap of the hair follicle cells is widened, and the } \\
\text { remaining changes are the same as above }\end{array}$ \\
\hline $10 \mathrm{~d}$ & $\begin{array}{l}\text { The cell hierarchy is severely disorganized, the structure } \\
\text { of the sweat glands can still be distinguished, no normal } \\
\text { epithelial cells, solid shrinking of the nuclei, nuclei are } \\
\text { broken up, karyolysis }\end{array}$ & Sebaceous cell nucleus disappears & $\begin{array}{l}\text { The number of hair follicle cells is reduced, and the } \\
\text { remaining changes are the same as above }\end{array}$ \\
\hline $12 \mathrm{~d}$ & $\begin{array}{l}\text { The cell hierarchy is severely disorganized, the structure } \\
\text { of sweat glands can still be distinguished, no normal } \\
\text { epithelial cells, shrunken solid nuclei, nuclei are broken } \\
\text { up, karyolysis }\end{array}$ & Sebaceous cell nucleus disappears & $\begin{array}{l}\text { The number of hair follicle cells are further reduced, } \\
\text { showing more nuclear pyknosis, nuclear fragmenta- } \\
\text { tion, and nuclear dissolution }\end{array}$ \\
\hline $16 \mathrm{~d}$ & Residual sweat gland structure & $\begin{array}{l}\text { Most of the sebocytes and basal cells are dissolved, leav- } \\
\text { ing a reddish floc }\end{array}$ & $\begin{array}{l}\text { Most of the hair follicle cells dissolve and disappear, } \\
\text { leaving a small amount of nuclear pyknosis, nuclear } \\
\text { fragmentation }\end{array}$ \\
\hline $20 \mathrm{~d}$ & Residual sweat gland structure & $\begin{array}{l}\text { Most of the sebocytes and basal cells are dissolved, leav- } \\
\text { ing a reddish floc }\end{array}$ & Only a few cells present, blurred hair follicle outline \\
\hline $24 \mathrm{~d}$ & Residual sweat gland structure & $\begin{array}{l}\text { Sebocytes and basal cells are completely dissolved, only } \\
\text { the sebaceous gland outline }\end{array}$ & No hair follicle structure \\
\hline $28 \mathrm{~d}$ & Residual sweat gland structure & No sebaceous gland structure & No hair follicle structure \\
\hline $32 \mathrm{~d}$ & No sweat gland structure & No sebaceous gland structure & No hair follicle structure \\
\hline
\end{tabular}

Table 2. Histological changes in sweat glands, sebaceous glands and hair follicles with time of death.

nuclear pyknosis and fragmentation. There is a junction between the epidermis and the dermis. In the contiguous purple-blue staining area, the dermal fibres are homogenized, the cells of the sebaceous glands and hair follicles are mostly dissolved, and only the remaining sweat gland structure is seen. Observation of the above histological changes depends on the experience and concentration of the examiner. The description of the changes under the microscope is difficult to quantify, so there may be some observer bias.

The variation in the human skin with the time of death can be used as an auxiliary means for inferring PMI. Our study, it was also found that the individual samples had different appearance times and rates of change after death, that is, individual differences and structural specificity after death. Therefore, it is speculated that PMI can not only be based on individual specific skin structure changes but should also be comprehensively observed. The composition and structure of the skin can be subjected to a comprehensive analysis.

In practice, the body has its own individual characteristics, such as sex, age, height, weight, disease, and cause of death. After death, it will be in various environmental conditions, such as temperature, humidity, air flow, water flow, insects, animal activities, etc. These factors will affect the post-mortem changes in the body. Our study investigated the histological changes in excised skin of eight cadaveric bodies at a lower ambient temperature and a longer time after death, filling in some gaps not covered by previous studies, but there are still many problems worth exploring, such as observing different individual characteristics, changes in the body under different environmental conditions after death, special staining to highlight a specific tissue structure, and quantitative analysis of specific microscopic targets to establish a quantifiable association between histological changes and time after death, all of which will be conducive for a more accurate inference of PMI.

In this study, there were only eight cadavers, which is a small number. In a future study, we will increase the sample size. In addition, the age range of the samples selected for this study was 22 and 33 years old, which is relatively limited, so the age range should be further broadened in future studies. 

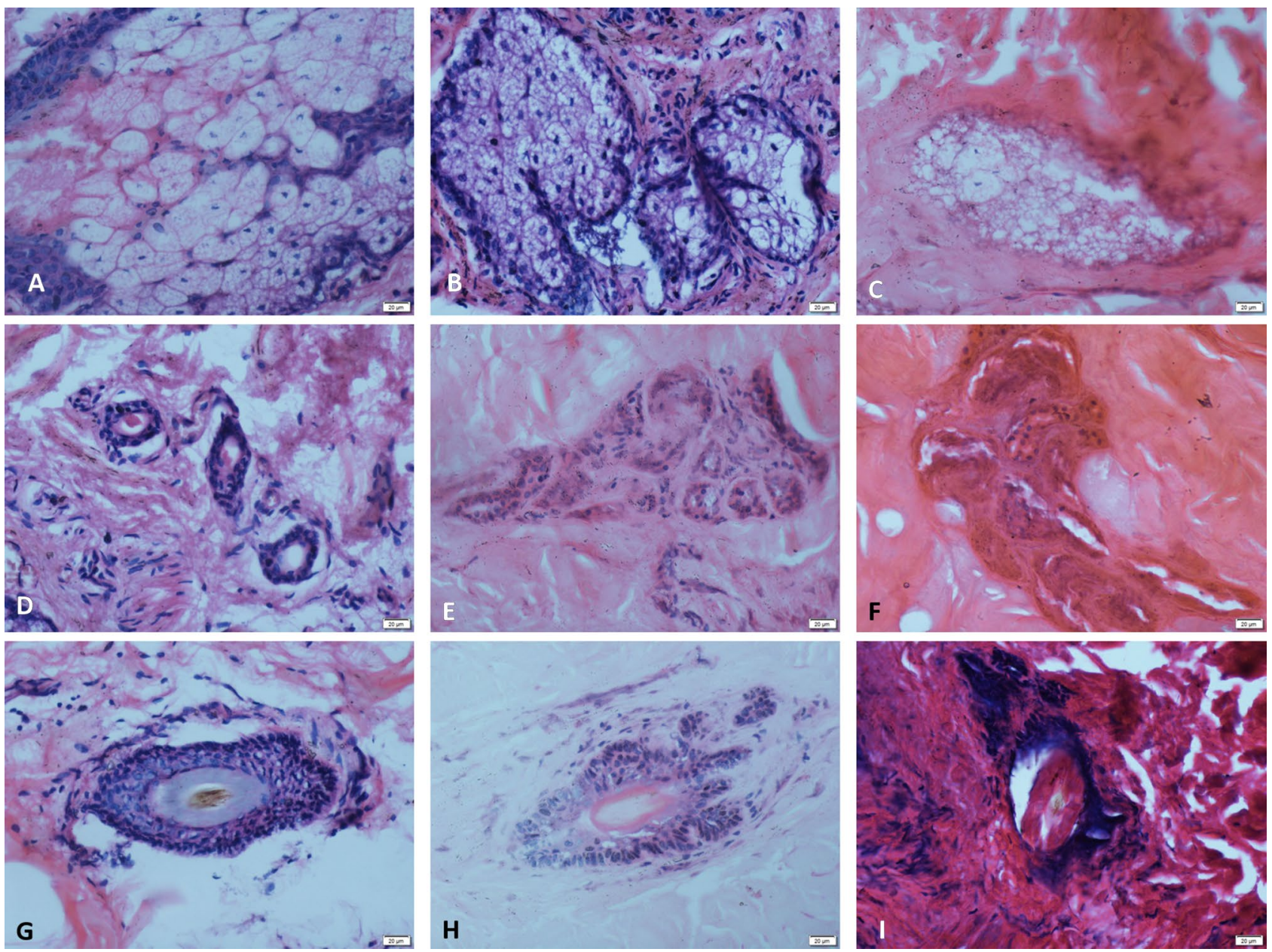

Figure 3. Microphotograph showing the sweat glands, sebaceous glands and hair follicles. (A, D, G) The sebaceous glands, sweat glands and hair follicles show no obvious change at the time of death. (B) Cytoplasmic changes in flocculation eight days after death. (C) Sebaceous cell nucleus disappears 10 days after death. (E) After 12 days of death, sweat glands lose most of their normal cells. (F) Residual sweat gland structure twenty days after death. (H) Cell gap widening six days after death. (I) Only the outline of the hair follicle can be seen 20 days after death $(\mathrm{H}$ and $\mathrm{E}$, original magnification $\times 40)$. (All images are collected by cellSens Standard software whose URL is https://www.olympus-lifescience.com.cn/en/software/cellsens/).

Received: 27 April 2020; Accepted: 22 October 2020

Published online: 30 October 2020

\section{References}

1. Jin, B. et al. Postmortem changes of biomechanics characteristic of the rats skin in different surrounding condition. Forensic Sci. Technol. 6, 13-16 (2011).

2. Sterzik, V., Belenkaia, L., Liehr, A. W. \& Bohnert, M. Spectrometric evaluation of post-mortem optical skin changes. Int. J. Legal Med. 128, 361-367. https://doi.org/10.1007/s00414-013-0855-2 (2014).

3. Huang, J. et al. Relationship between postmortem interval and FTIR spectroscopy changes of the rat skin. Fa Yi Xue Za Zhi 36, 187-191. https://doi.org/10.12116/j.issn.1004-5619.2020.02.008 (2020).

4. Usumoto, Y. et al. Estimation of postmortem interval based on the spectrophotometric analysis of postmortem lividity. Legal Med. (Tokyo, Japan) 12, 19-22. https://doi.org/10.1016/j.legalmed.2009.09.008 (2010).

5. Johnson, H. R. et al. A machine learning approach for using the postmortem skin microbiome to estimate the postmortem interval. PLoS ONE 11, e0167370. https://doi.org/10.1371/journal.pone.0167370 (2016).

6. Metcalf, J. L. Estimating the postmortem interval using microbes: Knowledge gaps and a path to technology adoption. Forensic Sci. Int. Genet. 38, 211-218. https://doi.org/10.1016/j.fsigen.2018.11.004 (2019).

7. Forger, L. V., Woolf, M. S., Simmons, T. L., Swall, J. L. \& Singh, B. A eukaryotic community succession based method for postmortem interval (PMI) estimation of decomposing porcine remains. Forensic Sci. Int. 302, 109838. https://doi.org/10.1016/j.forsc iint.2019.05.054 (2019).

8. Metcalf, J. L. et al. Microbiome tools for forensic science. Trends Biotechnol. 35, 814-823. https://doi.org/10.1016/j.tibte ch.2017.03.006 (2017).

9. Zhang, L. et al. Bacterial succession on rat carcasses and applications for PMI estimation. Fa Yi Xue Za Zhi 32, 1-6 (2016).

10. Canturk, I. et al. An experimental evaluation of electrical skin conductivity changes in postmortem interval and its assessment for time of death estimation. Comput. Biol. Med. 69, 92-96. https://doi.org/10.1016/j.compbiomed.2015.12.010 (2016). 
11. Querido, D. A preliminary investigation into postmortem changes in skinfold impedance during the early postmortem period in rats. Forensic Sci. Int. 96, 107-114. https://doi.org/10.1016/s0379-0738(98)00111-x (1998).

12. Ali, M. M., Ibrahim, S. F. \& Fayed, A. A. Using skin gene markers for estimating early postmortem interval at different temperatures. Am. J. Forensic Med. Pathol. 38, 323-325. https://doi.org/10.1097/paf.0000000000000337 (2017).

13. van den Berge, M., Wiskerke, D., Gerretsen, R. R., Tabak, J. \& Sijen, T. DNA and RNA profiling of excavated human remains with varying postmortem intervals. Int. J. Legal Med. 130, 1471-1480. https://doi.org/10.1007/s00414-016-1438-9 (2016).

14. Bardale, R. V., Tumram, N. K., Dixit, P. G. \& Deshmukh, A. Y. Evaluation of histologic changes of the skin in postmortem period. Am. J. Forensic Med. Pathol. 33, 357-361. https://doi.org/10.1097/PAF.0b013e31822c8f21 (2012).

15. El-Nahass, E. S., Moselhy, W. A. \& Hassan, N. E. Y. Forensic image analyses of skin and underlying muscles as a tool for postmortem interval delimitation: histopathologic examination. Am. J. Forensic Med. Pathol. 38, 131-138. https://doi.org/10.1097/paf.00000 00000000301 (2017).

16. Kovarik, C., Stewart, D. \& Cockerell, C. Gross and histologic postmortem changes of the skin. Am. J. Forensic Med. Pathol. 26, 305-308. https://doi.org/10.1097/01.paf.0000188087.18273.d2 (2005).

\section{Author contributions}

W.W., Q.M., H.Z. and J.B. conceptualized the design of the study. D.W., W.J., J.B. and Y.M. analysed the data. W.W, Q.M., J.B., H.Z., L.X. interpreted the data and drafted the manuscript. All authors revised the manuscript critically for important intellectual content.

\section{Funding}

This study was supported by grants from the Scientific Research Starting Foundation for Doctor of North Sichuan Medical College (No. CBY16-QD05), the Science and Technology Department Foundation of Sichuan Province (No. 2018JY0497), and the National and Sichuan Science and Technology Innovation Training Program for Undergraduates (No. 201810634009).

\section{Competing interests}

The authors declare no competing interests.

\section{Additional information}

Correspondence and requests for materials should be addressed to J.B. or L.X.

Reprints and permissions information is available at www.nature.com/reprints.

Publisher's note Springer Nature remains neutral with regard to jurisdictional claims in published maps and institutional affiliations.

(c) Open Access This article is licensed under a Creative Commons Attribution 4.0 International License, which permits use, sharing, adaptation, distribution and reproduction in any medium or format, as long as you give appropriate credit to the original author(s) and the source, provide a link to the Creative Commons licence, and indicate if changes were made. The images or other third party material in this article are included in the article's Creative Commons licence, unless indicated otherwise in a credit line to the material. If material is not included in the article's Creative Commons licence and your intended use is not permitted by statutory regulation or exceeds the permitted use, you will need to obtain permission directly from the copyright holder. To view a copy of this licence, visit http://creativecommons.org/licenses/by/4.0/.

(c) The Author(s) 2020 